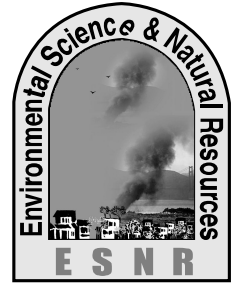

J. Environ. Sci. \& Natural Resources, 5(1): 211 - 215, 2012

ISSN 1999-7361

\title{
Effect of Inoculant on Yield and Yield Contributing Characters of Summer Mungbean Cultivars
}

\author{
M. Rahman ${ }^{1}$, M. Imran ${ }^{2}$ and M. Ashrafuzzaman ${ }^{3}$ \\ ${ }^{1}$ Dept. of Crop Botany, Bangladesh Agricultural University, Mymensingh. \\ ${ }^{2}$ Dept. of Environmental Science, Bangladesh Agricultural University, Mymensingh. \\ ${ }^{3}$ Dept. of Crop Botany, Bangladesh Agricultural University, Mymensingh.
}

\begin{abstract}
Anexperiment was conducted at Bangladesh Institute of Nuclear Agriculture (BINA) farm, Mymensingh to study the effect of rhizobial inoculant (biofertilizer) on the the yield and yield contributing characters of mungbean cultivars. Experimental treatments included two varieties of mungbean namely Binamoog5 and Binamoog7 and six inoculant treatments namely control $\left(\mathrm{I}_{0}\right)$, Bradyrhizobium Inoculant $(\mathrm{I})$, Inoculant $+\mathrm{P}$, NPK, Inoculant $+\mathrm{PK}+\mathrm{B}$ and Inoculant $+\mathrm{PK}+\mathrm{CD}$. Inoculantion $+\mathrm{PK}+\mathrm{B}$ obtained the highest grain yield of mungbean $\left(1.49 \mathrm{t} \mathrm{ha}^{-1}\right)$ while Inoculantion+PK+CD showed the highest straw yield. NPK application showed significantly higher grain and straw yield over uninoculated control and parallel to inoculation but statistically inferior to $\mathrm{I}+\mathrm{PK}+\mathrm{CD}$ in respect of grain yield. Inoculantion $+\mathrm{PK}+\mathrm{CD}$ or Inoculantion $+\mathrm{PK}+\mathrm{B}$ may be recommended for summer mungbean production where $\mathrm{I}+\mathrm{PK}+\mathrm{CD}$ is preferable.
\end{abstract}

Key words: Bradyrhizobium Inoculant, Mungbean (Vigna radiate)

\section{Introduction}

Mungbean (Vigna radiata L.) is one of the important pulse crops of Bangladesh, as it is an excellent source of easily digestible protein. It complements the staple rice diet in the country. Mungbean contains $51 \%$ carbohydrate, $26 \%$ protein, $4 \%$ minerals and $3 \%$ vitamins (Kaul, 1982). The green plants are used as animal feed and the residues as manure. The crop is potentially useful in improving cropping systems as cash crop due to its rapid growth and early maturing characteristics. In Bangladesh, the daily per capita consumption of pulses is only $13.29 \mathrm{~g}$ (BBS, 2001) where World Health Organization has suggested $45 \mathrm{~g}$ per capita per day for a balanced diet (BARI, 1998). Bangladesh Institute of Nuclear Agriculture (BINA) isolated Bradyrhizobium strains of bacteria which is known to influence biological nitrogen fixation and improve soil health and growth and yield of pulses. Inoculation with Bradyrhizobium increased 57\% effective nodules, $77 \%$ dry matter production, $64 \%$ grain yield and $40 \%$ hay yield over uninoculated control in mungbean cultivation. The use of Bradyrhizobium inoculants in crop production can play a vital role in improving soil environment and agricultural sustainability. Considering the above facts, the present study was undertaken to investigate the effect of Bradyrhizobium inoculant on the yield and yield contributing characters of mungbean, to study the varietal response of mungbean to inoculant and to find out a suitable combination of inoculant with other nutrient elements in sustainable mungbean production

\section{Materials and methods}

A field experiment was conducted at the field of Bangladesh Institute of Nuclear Agriculture (BINA), Mymensingh, during March to May 2011. The soil belongs to the Old Brahmaputra Alluvial under Agroecological Zone (AEZ) 9. The land topography was medium high, sandy loam textured with $\mathrm{P}^{\mathrm{H}}$ 6.7. The crops used in this study were two cultivars of Mungbean (Vigna radiata L.) named Binamoog-5 and Binamoog-7.

The study consists of two types to treatment as below:Factor- A. Crop variety: 2: Binamoog-5 and Binamoog-7. Factor- B. Biofertilizer and chemical fertilizers: 1.Control $\left(\mathrm{I}_{0}\right)$ 2.Inoculant (I) 3 . Inoculant+Phosphorus@25 kg P ha $^{-1}$ and Potassium@40 kg P ha ${ }^{-1}$ (I+PK) 4.Nitrogen(@30 N kg ha ${ }^{-1}+$ Phosphorus@25 P kg ha ${ }^{-1}+$ Potassium@40 $\mathrm{kg} \mathrm{K} \mathrm{ha}^{-1}$ (NPK) 5. Inoculants+ Phosphorus@25 kg P $\mathrm{ha}^{-1}$ and Potassium@40 kg P ha ${ }^{-1}+$ Boron@2 kg B ha ${ }^{1}$ (I+PK+B) 6. Inoculants+ Phosphorus@25 kg P haand Potassium@40kg P ha ${ }^{-1}+$ Cowdung@3ton ha ${ }^{-1}$ $(\mathrm{I}+\mathrm{PK}+\mathrm{CD}$. The experiment was laid out in split plot design with three replications. Each replication had 14 unit plots in which the treatment combinations were assigned at random. The total number of subplots were 36 and size of each plot was $4 \mathrm{~m}$ x $3 \mathrm{~m}$ $\left(12 \mathrm{~m}^{2}\right)$.

The Bradyrhizobium strains used in the present study were collected from the Soil Microbiology 
Laboratory of Bangladesh Institute of Nuclear Agriculture (BINA), Mymensingh and were inoculated into yeast mannitol broth medium containing $250 \mathrm{ml}$ Erlenmeyer flask under laminar air flow cabinet. The amount of seed in each packet was mixed thoroughly with mentioned liquid culture. The line to line distance was $30.0 \mathrm{~cm}$ with continuous dropping of seeds in the line and depth of sowing was about $3 \mathrm{~cm}$. Germination was more than $80 \%$. Weeding, thinning and irrigation was done time to time. The crops were harvested on different dates when they attained maturity. From $1 \mathrm{~m}^{2}$ area of each plot, plants were selected for recording data. The collected seeds were dried in the sun for reducing the moisture in the seeds to about $14 \%$ level. Data were recorded on different parameters. The data were analyzed statistically using MSTAT and mean differences were classified by Duncan's Multiple Range Test' (Gomez and Gomez, 1984).

\section{Results and Discussion}

The remarkable effect of biofertilizer on the cultivars and their interaction effects were apparent from the data presented. The results obtained on grain yield, straw yield, 1000 grain weight, grain weight plant $^{-1}$, husk weight plant ${ }^{-1}$, number of grain plant ${ }^{-1}$, number of branch, pod number plant ${ }^{-1}$, number of grain pod $^{-1}$ and pod length have been presented in Table 1,2 and 3 and discussed below.

\section{Grain yield}

Grain yield of mungbean was highly significant due to bradyrhizobial inoculants. The highest grain yield was recorded due to the application of treatment $\mathrm{I}+\mathrm{PK}+\mathrm{B}$ followed by treatment $\mathrm{I}+\mathrm{PK}+\mathrm{CD}$. All the inoculated and nitrogen treatments recorded significantly higher grain yield of mungbean compared to uninoculated control. A similar type of results have been, reported by Shukla and Dixit (1996) and Solaiman (2002), those are reported that application of inoculants increase mungbean yield .The effect of cultivars on seed yield of mungbean was not significant. The maximum seed yield was recorded by the interaction of Binamoog $7 \times$ $\mathrm{I}+\mathrm{PK}+\mathrm{CD}$ treatment.

\section{Straw yield}

Inoculated and NPK treated plots gave significantly higher straw yield compared to uninoculated control one. The highest straw yield was produced due to application of $\mathrm{I}+\mathrm{PK}+\mathrm{CD}$ treatment which was identical to $\mathrm{I}+\mathrm{PK}+\mathrm{B}$ and $\mathrm{I}+\mathrm{PK}$. Inoculation without $\mathrm{PK}$ or $\mathrm{PK}+\mathrm{B}$ or $\mathrm{PK}+\mathrm{CD}$ show significantly lower straw yield compared to $\mathrm{PK}$ or $\mathrm{PK}+\mathrm{B}$ or $\mathrm{PK}+\mathrm{CD}$ with inoculation. These results were consistent with the results of Gill et al. (1985) who reported that inoculation significantly increased seed and straw yield. Binamoog7 produced higher straw yield over Binamoog5. The maximum straw yield was recorded by the interaction of Binamoog $7 \times \mathrm{I}+\mathrm{PK}+\mathrm{CD}$ where lowest straw yield was observed by the interaction of Binamoog $7 \times$ uninoculated control

\section{0-grain weight}

The highest 1000-seed weight was recorded in $\mathrm{I}+\mathrm{PK}+\mathrm{CD}$ followed by $\mathrm{I}+\mathrm{PK}+\mathrm{B}$ treatment . The uninoculated control gave the lowest 1000-seed weight . Binamoog5 produced significantly higher 1000-seed weight over Binamoog7. The maximum 1000-grain weight was recorded with treatment combination Binamoog5 $\times \mathrm{I}+\mathrm{PK}$ and the lowest 1000-grain weight was observed by the interaction of Binamoog $7 \times$ uninoculated control $\left(\mathrm{I}_{0}\right)$.

\section{Grain weight per plant}

Treatment $\mathrm{I}+\mathrm{PK}+\mathrm{B}$ produced the highest grain weight plant $^{-1}$ followed by $\mathrm{I}+\mathrm{PK}+\mathrm{CD}$. All the inoculated as well as NPK treated plot showed significantly higher grain weight per plant. The lowest grain weight plant ${ }^{-1}$ was produced in uninoculated treatment $\left(\mathrm{I}_{0}\right)$. Binamoog7 produced higher grain weight plant $^{-1}$ over Binamoog5. The highest grain weight plant $^{-1}$ was recorded with interaction of Binamoog $7 \times \mathrm{I}+\mathrm{PK}+\mathrm{B}$ treatments.

\section{Husk weight per plant}

All the treatment (inoculant+NPK) showed significantly higher husk yield plant ${ }^{-1}$ over control. The highest husk weight was produced due to application of $\mathrm{I}+\mathrm{PK}+\mathrm{B}$ treatment. The lowest husk weight was obtained in uninoculated treatment. NPK treated plots produced also lowest husk weight .Similar result was reported by Gil et al. (1985), who reported that application of inoculants have significant effect on husk weight. Binamoog5 produced higher husk weight over Binamoog7. The highest husk weight plant $^{-1}$ was recorded with interaction of Binamoog $5 \times \mathrm{I}+\mathrm{PK}+\mathrm{B}$ treatments.

\section{Number of branch plant}

The highest number of branch plant ${ }^{-1}$ was recorded in inoculated treatment. Which was statistically similar to $\mathrm{I}+\mathrm{PK}+\mathrm{B}$ and $\mathrm{I}+\mathrm{PK}+\mathrm{CD}$. The lowest number of branch plant ${ }^{-1}$ was found in control treatment. The effect of cultivars on the number of branch of mungbean was not significant. The 
maximum number of branch plant ${ }^{-1}$ was recorded by the interaction of Binamoog $5 \mathrm{x}$ I treatment.

Table 1. Effect of biofertilizer on grain yield, straw yield, 1000 grain weight, grain weight plant ${ }^{-1}$, husk weight plant ${ }^{-1}$ and number of branch plant ${ }^{-1}$ of mungbean

\begin{tabular}{|c|c|c|c|c|c|c|}
\hline Inoculant & $\begin{array}{l}\text { Grain yield (t } \\
\left.\text { ha }^{-1}\right)\end{array}$ & $\begin{array}{c}\text { Straw yield (t } \\
\left.\mathrm{ha}^{-1}\right)\end{array}$ & $\begin{array}{l}1000 \text { grain } \\
\text { weight }(\mathrm{g})\end{array}$ & $\begin{array}{c}\text { Grain weight } \\
\text { plant }^{-1}(\mathrm{~g})\end{array}$ & $\begin{array}{c}\text { Husk weight } \\
\text { plant }^{-1}(\mathrm{~g})\end{array}$ & $\begin{array}{l}\text { No. of } \\
\text { branch } \\
\text { plant }^{-1}\end{array}$ \\
\hline $\mathrm{I}_{0}$ & $0.75 d$ & $5.35 \mathrm{~d}$ & $29.50 \mathrm{c}$ & $2.63 \mathrm{~d}$ & $3.26 \mathrm{e}$ & $2.41 \mathrm{c}$ \\
\hline I & $1.15 \mathrm{c}$ & $6.57 \mathrm{c}$ & $32.50 \mathrm{~b}$ & $3.37 \mathrm{c}$ & $4.07 \mathrm{~cd}$ & $3.16 \mathrm{a}$ \\
\hline $\mathrm{I}+\mathrm{PK}$ & $1.26 \mathrm{~b}$ & $7.38 \mathrm{ab}$ & $33.65 \mathrm{ab}$ & $3.85 b$ & $3.89 \mathrm{~d}$ & $2.83 b$ \\
\hline NPK & $1.14 \mathrm{c}$ & $6.95 \mathrm{bc}$ & $33.75 \mathrm{ab}$ & $3.92 b$ & $4.11 \mathrm{c}$ & $2.96 \mathrm{ab}$ \\
\hline $\mathrm{I}+\mathrm{PK}+\mathrm{B}$ & $1.49 \mathrm{a}$ & $7.47 \mathrm{ab}$ & $34.08 \mathrm{a}$ & $4.23 \mathrm{a}$ & $4.59 \mathrm{a}$ & $3.13 \mathrm{a}$ \\
\hline $\mathrm{I}+\mathrm{PK}+\mathrm{CD}$ & $1.47 \mathrm{a}$ & $7.57 \mathrm{a}$ & $34.65 a$ & $4.19 \mathrm{a}$ & $4.34 \mathrm{~b}$ & $3.13 \mathrm{a}$ \\
\hline Significant level & $* *$ & $* *$ & $* *$ & $* *$ & $* *$ & $* *$ \\
\hline $\mathrm{CV}(\%)$ & 4.57 & 6.11 & 2.22 & 4.24 & 4.11 & 5.43 \\
\hline
\end{tabular}

Table 2. Response of cultivars on grain yield, straw yield, 1000 grain weight, grain weight plant ${ }^{-1}$, husk weight plant ${ }^{-1}$ and number of branch plant ${ }^{-1}$ of mungbean

\begin{tabular}{|l|c|c|c|c|c|c|}
\hline Cultivar & $\begin{array}{c}\text { Grain yield } \\
\left(\mathrm{t} \mathrm{ha}^{-1}\right)\end{array}$ & $\begin{array}{c}\text { Straw yield } \\
\left(\mathrm{t} \mathrm{ha}^{-1}\right)\end{array}$ & $\begin{array}{c}1000 \text { grain } \\
\text { weight }(\mathrm{g})\end{array}$ & $\begin{array}{c}\text { Grain weight } \\
\text { plant }^{-1}(\mathrm{~g})\end{array}$ & $\begin{array}{c}\text { Husk weight } \\
\text { plant }\end{array}$ & $\begin{array}{c}\text { No. of } \\
\text { branch } \\
\text { plant }^{-1}\end{array}$ \\
\hline Binamoog5 & 1.213 & $6.47 \mathrm{~b}$ & $33.83 \mathrm{a}$ & $3.34 \mathrm{~b}$ & $4.69 \mathrm{a}$ & 2.918 \\
\hline Binamoog7 & 1.212 & $7.29 \mathrm{a}$ & $32.22 \mathrm{~b}$ & $4.06 \mathrm{a}$ & $3.39 \mathrm{~b}$ & 2.958 \\
\hline Significant level & $\mathrm{NS}$ & $* *$ & $* *$ & $* *$ & $* *$ & $\mathrm{NS}$ \\
\hline CV(\%) & 4.57 & 6.11 & 2.22 & 4.24 & 4.11 & 5.43 \\
\hline
\end{tabular}

Table 3. Interaction effect of inoculant and chemical fertilizers and cultivars on grain yield, straw yield, 1000 grain weight, grain weight plant ${ }^{-1}$, husk weight plant ${ }^{-1}$ and number of branch plant ${ }^{-1}$ of mungbean

\begin{tabular}{|l|c|c|c|c|c|c|}
\hline Inoculant $\times$ Cultivar & $\begin{array}{c}\text { Grain yield }(\mathrm{t} \\
\left.\mathrm{ha}^{-1}\right)\end{array}$ & $\begin{array}{c}\text { Straw yield } \\
\left(\mathrm{t} \mathrm{ha}^{-1}\right)\end{array}$ & $\begin{array}{c}1000 \text { grain } \\
\text { weight }(\mathrm{g})\end{array}$ & $\begin{array}{c}\text { Grain weight } \\
\text { plant }^{-1}(\mathrm{~g})\end{array}$ & $\begin{array}{c}\text { Husk weight } \\
\text { plant }\end{array}$ & $\begin{array}{c}\text { No.of } \\
(\mathrm{g}) \\
\text { Branch }^{-1} \\
\text { llant }^{-1}\end{array}$ \\
\hline $\mathrm{V}_{1} \times \mathrm{I}_{0}$ & $0.74 \mathrm{f}$ & $5.50 \mathrm{e}$ & $30.00 \mathrm{e}$ & $2.30 \mathrm{~g}$ & $3.78 \mathrm{~cd}$ & $2.33 \mathrm{f}$ \\
\hline $\mathrm{V}_{1} \times \mathrm{I}$ & $1.12 \mathrm{de}$ & $6.87 \mathrm{~cd}$ & $33.00 \mathrm{~cd}$ & $2.96 \mathrm{f}$ & $4.65 \mathrm{~b}$ & $3.66 \mathrm{a}$ \\
\hline $\mathrm{V}_{1} \times \mathrm{I}+\mathrm{PK}$ & $1.3 \mathrm{c}$ & $6.65 \mathrm{~d}$ & $35.30 \mathrm{a}$ & $3.55 \mathrm{~d}$ & $4.55 \mathrm{~b}$ & $2.73 \mathrm{cde}$ \\
\hline $\mathrm{V}_{1} \times \mathrm{NPK}$ & $1.19 \mathrm{de}$ & $6.40 \mathrm{~d}$ & $35.00 \mathrm{a}$ & $3.41 \mathrm{e}$ & $4.72 \mathrm{~b}$ & $2.93 \mathrm{~cd}$ \\
\hline $\mathrm{V}_{1} \times \mathrm{I}+\mathrm{PK}+\mathrm{B}$ & $1.48 \mathrm{ab}$ & $6.71 \mathrm{~d}$ & $34.67 \mathrm{ab}$ & $3.75 \mathrm{~b}$ & $5.26 \mathrm{a}$ & $2.93 \mathrm{~cd}$ \\
\hline $\mathrm{V}_{1} \times \mathrm{I}+\mathrm{PK}+\mathrm{CD}$ & $1.42 \mathrm{~b}$ & $6.74 \mathrm{~d}$ & $35.00 \mathrm{a}$ & $4.09 \mathrm{c}$ & $5.20 \mathrm{a}$ & $2.93 \mathrm{~cd}$ \\
\hline $\mathrm{V}_{2} \times \mathrm{I}_{0}$ & $0.75 \mathrm{f}$ & $5.20 \mathrm{e}$ & $29.00 \mathrm{e}$ & $2.97 \mathrm{f}$ & $2.74 \mathrm{f}$ & $2.50 \mathrm{ef}$ \\
\hline $\mathrm{V}_{1} \times \mathrm{I}$ & $1.16 \mathrm{de}$ & $6.280 \mathrm{~d}$ & $32.00 \mathrm{bd}$ & $3.79 \mathrm{~d}$ & $3.50 \mathrm{de}$ & $2.66 \mathrm{de}$ \\
\hline $\mathrm{V}_{2} \times \mathrm{I}+\mathrm{PK}$ & $1.21 \mathrm{~d}$ & $8.12 \mathrm{ab}$ & $32.00 \mathrm{~cd}$ & $4.15 \mathrm{bc}$ & $3.23 \mathrm{e}$ & $2.93 \mathrm{~cd}$ \\
\hline $\mathrm{V}_{2} \times \mathrm{NPK}$ & $1.10 \mathrm{e}$ & $7.50 \mathrm{bc}$ & $32.50 \mathrm{bc}$ & $4.43 \mathrm{~b}$ & $3.51 \mathrm{de}$ & $3.00 \mathrm{c}$ \\
\hline $\mathrm{V}_{2} \times \mathrm{I}+\mathrm{PK}+\mathrm{B}$ & $1.50 \mathrm{ab}$ & $8.24 \mathrm{ab}$ & $33.50 \mathrm{ab}$ & $4.72 \mathrm{a}$ & $3.93 \mathrm{c}$ & $3.33 \mathrm{~b}$ \\
\hline $\mathrm{V}_{2} \times \mathrm{I}+\mathrm{PK}+\mathrm{CD}$ & $1.53 \mathrm{a}$ & $8.40 \mathrm{a}$ & $34.30 \mathrm{ab}$ & $4.30 \mathrm{bc}$ & $3.48 \mathrm{de}$ & $3.33 \mathrm{~b}$ \\
\hline Significant level & $* *$ & $*$ & $*$ & $* * 2$ & $*$ & $* *$ \\
\hline $\mathrm{CV}(\%)$ & 4.57 & 6.11 & 2.22 & 4.24 & 4.11 & 5.43 \\
\hline
\end{tabular}

In a column same letter(s) do not differ significantly at 1 and 5\% level of probability as per DMRT.

$* *=$ Significance at $1 \%$ level of probability, $*=$ Significance at $5 \%$ level of probability

Effect of inoculant on grains plant ${ }^{-1}$, pod plant ${ }^{-1}$, pod lengh and grain no. pod ${ }^{-1}$ and their interactions are shown in Table 4, 5 and 6 and are described here

\section{Number of grains plant ${ }^{-1}$}

The highest number of grain plant ${ }^{-1}$ was recorded by $\mathrm{I}+\mathrm{PK}+\mathrm{CD}$ treatment followed by $\mathrm{I}+\mathrm{PK}+\mathrm{B}, \mathrm{I}+\mathrm{PK}$ and 
NPK. PK and PK+B exhibited higher grains plant ${ }^{-1}$ over inoculation only with $\mathrm{PK}$ or $\mathrm{PK}+\mathrm{B}$. The lowest number of grain plant ${ }^{-1}$ was recorded in control $\left(\mathrm{I}_{0}\right)$ treatment.Binamoog7 produced statistically higher number of seeds than Binamoog5. The highest

\section{Number of pod plant ${ }^{-1}$}

The highest number of pod plant $^{-1}$ was recorded in $\mathrm{I}+\mathrm{PK}+\mathrm{CD}$ treatment followed by NPK and $\mathrm{I}+\mathrm{PK}+\mathrm{B}$. Inoculation with phosphorus and potassium application enhanced the number of pod significantly over inoculation only. This result was in conformity with the findings of Gill et al. (1985) who reported that inoculation significantly increased the number of pod plant ${ }^{-1}$. Binamoog 5 produced higher number of pods plant ${ }^{-1}$ over Binamoog7. The highest number of pod plant ${ }^{-1}$ was observed in Binamoog $5 \mathrm{x}$ $\mathrm{I}+\mathrm{PK}+\mathrm{CD}$.

\section{Pod length}

The maximum pod length was recorded with the application of $\mathrm{I}+\mathrm{PK}+\mathrm{CD}$. Inoculated and NPK treated pods were found statistically similar pod length. number of grains plant $^{-1}$ was observed in the interaction of Binamoog $7 \times \mathrm{I}+\mathrm{PK}+\mathrm{B}$ and the lowest number of grain plant ${ }^{-1}$ was observed in the interaction of Binamoog5 x control.

Binamoog5 produced significantly higher pod length over Binamoog7. This result was similar with the findings of Thakuria and Shaharia (1990) who observed that different varieties of mungbean differed significantly in pod length. The highest length of pod was observed in the interaction of Binamoog $5 \times$ I treatment followed by Binamoog $5 \times$ $\mathrm{I}+\mathrm{PK}+\mathrm{CD}$.

\section{Number of grain per pod}

The highest number of seed pod $^{-1}$ was recorded in inoculated (I) treatment which was identical to I+PK, NPK and I+PK+CD. The lowest number of seed pod ${ }^{1}$ was recorded in control $\left(\mathrm{I}_{0}\right)$ treatment. Banamoog5 produced significantly higher number of seed pod $^{-1}$ ompared to Binamoog7. The highest number of seed pod $^{-1}$ was observed in Binamoog7 x I+PK+CD.

Table 4. Effect of inoculant on number of grain plant ${ }^{-1}$, number of pod plant ${ }^{-1}$, pod length and number of grain pod $^{-1}$ of mungbean

\begin{tabular}{|c|c|c|c|c|}
\hline Inoculant & No. of grain plant ${ }^{-1}$ & No. of pod plant ${ }^{-1}$ & Pod length $(\mathrm{cm})$ & No. of grain pod ${ }^{-1}$ \\
\hline $\mathrm{I}_{0}$ & $65.63 c$ & $16.50 \mathrm{~d}$ & $4.89 b$ & $3.88 \mathrm{c}$ \\
\hline I & $80.60 \mathrm{~b}$ & $19.39 \mathrm{c}$ & $5.50 \mathrm{a}$ & $5.27 \mathrm{a}$ \\
\hline $\mathrm{I}+\mathrm{PK}$ & $83.00 \mathrm{ab}$ & $20.72 b$ & $5.67 \mathrm{a}$ & $4.93 \mathrm{ab}$ \\
\hline NPK & $81.48 \mathrm{ab}$ & $22.92 \mathrm{a}$ & $5.46 a$ & $4.90 \mathrm{ab}$ \\
\hline $\mathrm{I}+\mathrm{PK}+\mathrm{B}$ & 83.00ab & $22.70 \mathrm{a}$ & $5.50 \mathrm{a}$ & $4.70 \mathrm{~b}$ \\
\hline $\mathrm{I}+\mathrm{PK}+\mathrm{CD}$ & $84.95 \mathrm{a}$ & $24.01 \mathrm{a}$ & $5.71 \mathrm{a}$ & $4.92 \mathrm{ab}$ \\
\hline Significant level & $* *$ & ** & ** & ** \\
\hline $\mathrm{CV}(\%)$ & 4.09 & 5.10 & 3.73 & 6.48 \\
\hline
\end{tabular}

Table 5. Response of cultivars on number of grain plant ${ }^{-1}$, number of pod plant ${ }^{-1}$, pod length and number of grain pod $^{-1}$ of mungbean

\begin{tabular}{|l|c|c|c|c|}
\hline Cultivar & No. of grain plant & No. of pod plant & Pod length (cm) & No. of grain pod $^{-1}$ \\
\hline Binamoog5 & $74.05 \mathrm{~b}$ & $22.69 \mathrm{a}$ & $5.540 \mathrm{a}$ & $4.25 \mathrm{~b}$ \\
\hline Binamoog7 & $85.50 \mathrm{a}$ & $19.39 \mathrm{~b}$ & $5.375 \mathrm{~b}$ & $5.28 \mathrm{a}$ \\
\hline Significant level & $* *$ & $* *$ & $* *$ & $* *$ \\
\hline CV(\%) & 4.09 & 5.10 & 3.73 & 6.48 \\
\hline
\end{tabular}


Table 6. Interaction effect of inoculant and cultivars on number of grain plant ${ }^{1}$, number of pod plant ${ }^{-1}$, pod length and number of grain pod $^{-1}$ of mungbean

\begin{tabular}{|l|c|c|c|c|}
\hline Inoculant $\times$ Cultivar & No. of grain plant & No. of pod plant & Pod length (cm) $^{-1}$ & No. of grain pod $^{-1}$ \\
\hline $\mathrm{V}_{1} \times$ Io & $59.40 \mathrm{f}$ & $17.60 \mathrm{~d}$ & $4.83 \mathrm{e}$ & $3.57 \mathrm{~d}$ \\
\hline $\mathrm{V}_{1} \times \mathrm{I}$ & $79.10 \mathrm{~cd}$ & $20.07 \mathrm{bc}$ & $5.87 \mathrm{a}$ & $5.11 \mathrm{~b}$ \\
\hline $\mathrm{V}_{1} \times \mathrm{I}+\mathrm{PK}$ & $77.00 \mathrm{cde}$ & $22.00 \mathrm{~b}$ & $5.69 \mathrm{abc}$ & $4.47 \mathrm{c}$ \\
\hline $\mathrm{V}_{1} \times \mathrm{NPK}$ & $75.56 \mathrm{de}$ & $25.30 \mathrm{a}$ & $5.44 \mathrm{bcd}$ & $4.30 \mathrm{c}$ \\
\hline $\mathrm{V}_{1} \times \mathrm{I}+\mathrm{PK}+\mathrm{B}$ & $74.66 \mathrm{de}$ & $24.75 \mathrm{a}$ & $5.64 \mathrm{abc}$ & $4.00 \mathrm{~cd}$ \\
\hline $\mathrm{V}_{1} \times \mathrm{I}+\mathrm{PK}+\mathrm{CD}$ & $78.60 \mathrm{~cd}$ & $26.40 \mathrm{a}$ & $5.77 \mathrm{ab}$ & $4.09 \mathrm{~cd}$ \\
\hline $\mathrm{V}_{2} \times$ Io & $71.86 \mathrm{e}$ & $15.40 \mathrm{e}$ & $4.96 \mathrm{e}$ & $4.19 \mathrm{c}$ \\
\hline $\mathrm{V}_{1} \times \mathrm{I}$ & $82.10 \mathrm{bc}$ & $18.70 \mathrm{~cd}$ & $5.13 \mathrm{de}$ & $5.44 \mathrm{ab}$ \\
\hline $\mathrm{V}_{2} \times \mathrm{I}+\mathrm{PK}$ & $89.00 \mathrm{a}$ & $19.43 \mathrm{~cd}$ & $5.66 \mathrm{abc}$ & $5.39 \mathrm{ab}$ \\
\hline $\mathrm{V}_{2} \times \mathrm{NPK}$ & $87.40 \mathrm{ab}$ & $20.53 \mathrm{bc}$ & $5.48 \mathrm{bcd}$ & $5.50 \mathrm{ab}$ \\
\hline $\mathrm{V}_{2} \times \mathrm{I}+\mathrm{PK}+\mathrm{B}$ & $91.33 \mathrm{a}$ & $20.66 \mathrm{bc}$ & $5.37 \mathrm{~cd}$ & $5.41 \mathrm{ab}$ \\
\hline $\mathrm{V}_{2} \times \mathrm{I}+\mathrm{PK}+\mathrm{CD}$ & $91.30 \mathrm{a}$ & $21.63 \mathrm{~b}$ & $5.65 \mathrm{abc}$ & $5.76 \mathrm{a}$ \\
\hline Significant level & $*$ & $*$ & $* *$ & 3.73 \\
\hline $\mathrm{CV}(\%)$ & 4.09 & 5.10 & & 6.48 \\
\hline
\end{tabular}

In a column same letter(s) do not differ significantly at 1 and $5 \%$ level of probability as per DMRT.

$* *=$ Significance at $1 \%$ level of probability $*=$ Significance at $5 \%$ level of probability

\section{Summary and Conclusions}

From the above discussion, it may be concluded that in most cases or parameters inoculated treatments exhibited better result over uninoculated control. Inoculation along with phosphorus and potassium application further enhanced yield of mungbean. Inoculation along with PK and boron or cowdung further combindly enhanced the effectivity of biofertilizer and influenced yield and yield attributing characters of mungbean and finally recorded the highest yield of grain and straw. When the crop mungbean was inoculated with rhizobial along with recommended $\mathrm{P}, \mathrm{K}$ and boron the grain yield was achieved highest but when boron replaced with cowdung the straw yield got highest. Though these two treatments are very close, as the treatment $\mathrm{I}+\mathrm{PK}+\mathrm{CD}$ gave the highest straw yield and it content also a small amount of boron also. So treatment I+PK+CD may be used for summer mungbean production.

\section{References}

BARI. (Bangladesh Agricultural Research Institute). 1998. Mungbean Cultivation in Bangladesh. A booklet in Bengali. Bangladesh Agril. Res. Insti., Joydebpur, Gazipur.

BBS. 2001. Statistical Yearbook of Bangladesh. Bangladesh Bureau of Statistics. Statistics Division, Ministry of Planning, Govt. People's Republic Bangladesh, Dhaka. pp. 61- 3 and 581.

Gill, M.A., Naimat, A. and Nayyer, M.M. 1985. Relative effect of phosphorus combined with potash and Rhizobium phaseoli on the yield of Vigna radiata (mung). Pakistan J. Agril. Res. 23(4): 279-
282.

Gomez, K. A. and Gomez A. A. 1984. Statistical Procedure for Agricultural Research. International Rice Research Institute, John Willey and Sons, Inc. Singapore. pp. 139-240.

Kaul, A.K. 1982. Pulses in Bangladesh. BARC, Farmgate, Dhaka. Bangladesh. 27p.

Kavethia, Y.A. and Pandey, R.N. 2000. Interaction studies on Meloidogyne javanica, Bradyrhizobium species and Macrophomina phaseolina in mungbean. J. Mycol. Plant. Pthol. 30(1):91-93.

Patra, D.K. and Bhattacharya, P. 1998. Response of cowpea rhizobia on nodulation and yield of mungbean (Vigna radiata L. wilczek). $J$. Mycopathol. Res. 36(1):17-23.

Shukla, S.K. and Dixit, R.S. 1996. Effect of Rhizobium inoculation, plant population and phosphorus on growth and yield of summer mungbean (Vigna radiata). Indian J. Agron. 41(4): 611-615.

Solaiman, M.N. 2002. Effect of nitrogen fertilizer and biofertilizer on the growth and yield of summer mungbean (Vigna radiata L.). An M.S. in Soil Sci. Thesis.

Thakuria, A. and Saharia, P. 1990. Response of green gram genotypes to plant density and phosphorus levels in summer. Indian J. 35(4):431-432. 